\title{
The Man That Was a Thing: Reconsidering Human Commodification in Slavery
}

\begin{abstract}
This essay examines a longstanding normative assumption in the historiography of slavery in the Atlantic world: that enslaved Africans and their American-born descendants were bought and sold as "commodities," thereby "dehumanizing" them and treating them as things rather than as persons. Such claims have, indeed, helped historians conceptualize how New World slavery contributed to the ongoing development of global finance capitalism-namely, that slaves represented capital as well as labor. But the recurring paradigm of the "dehumanized" or "commodified" slave, I argue, obscures more than it reveals.

This article suggests that historians of slavery must reconsider the "commodification" of enslaved humanity. In so doing, it offers three interrelated arguments: first, that scholarship on slavery has not adequately or coherently defined the precise mechanisms by which enslaved people were supposedly "commodified"; second, that the normative position implied by the insistence that persons were treated as things further mystifies or clouds our collective historical vision of enslavement; and third, that we should abandon a strictly Marxian conception of the commodity - and its close relation to notions of "social death" - in favor of Igor Kopytoff's theory of the commodity-as-process. It puts forth in closing a reconstituted conceptualization of the slave relation wherein enslaved people are understood as thoroughly human.
\end{abstract}

Book titles tell the story. The original subtitle for Uncle Tom's Cabin was "The Man Who Was a Thing." In 1910 appeared a book by Mary White Ovington called Half a Man. Over one hundred years after the appearance of the Stowe book, The Man Who Cried I Am, by John A. Williams, was published. Quickskill thought of all of the changes that would happen to make a "Thing" into an "I Am." Tons of paper. An Atlantic of blood. Repressed energy of anger that would form enough sun to light a solar system. A burnt-out black hole. A cosmic slave hole.

—Ishmael Reed, Flight to Canada (1976)

Between the modern master and the nonmodern slave, one must choose the slave not because one should choose voluntary poverty or admit the superiority

Journal of Social History (2016), pp. 1-23

doi: $10.1093 /$ jsh/shv129

(C) The Author 2016. Published by Oxford University Press. All rights reserved.

For permissions, please e-mail: journals.permissions@oup.com. 
of suffering, not only because the slave is oppressed, not even because he works (which, Marx said, made him less alienated than the master). One must choose the slave also because he represents a higher-order cognition which perforce includes the master as a human, whereas the master's cognition has to exclude the slave except as a "thing."

—Ashis Nandy, The Intimate Enemy (1983)

The commodity might like to be human, but humanity, within the system of capital, is ownership.... There are objects and there are owners. When there are owners, one is either object or owner. Objects capable of ownership and exchange are commodities. One owns or does not own. The one that owns is an owner and the one that does not own is either owned or lost. Of the lost, nothing can be said. Of the owned, nothing need be said; they speak with the voice of their owners, they speak of rights.

—Anthony Farley, "The Apogee of the Commodity" (2004)

\section{Introduction}

It has become something of a truism, or a conclusion taken for granted, in the recent historiography of slavery that Africans and their descendants captured, sold, and transported across great stretches of land and sea in the Atlantic slave trade and the internal slave trades of the New World were reduced from complex human subjects with extensive personal and collective histories to readily exchangeable objects - in simple terms, that these persons were made into things. This compulsion on the part of historians and other writers often expresses itself in terms of the "commodification" or "dehumanization" of enslaved people. ${ }^{1}$ According to this line of thought, enslaved humanity was compressed, flattened, or erased as it came to be seen as a marketable good in Atlantic cycles of exchange. This logic also implies that the history of slavery, both across the Atlantic and throughout the New World, contributed to the emergence and expansion of global capitalism not only because slaves produced valuable cash crops for export in the Americas but also because these slaves themselves were bought and sold as goods in a market buttressed by financial speculation-in short, that they were capital as well as labor. ${ }^{2}$

This essay aims first to question the historical claims and normative assumptions according to which enslaved people were "commodified" as such and then to suggest new ways to theorize the history of enslavement that do not make recourse to this particularly unproductive cliché. It begins with the presumption that the question of "commodified" humanity in the history of Atlantic slavery has not been adequately examined or questioned. In surveying recent historical scholarship on both the Atlantic slave trade and the internal slave trades of the Americas, I propose three interrelated arguments: first, that scholars have not adequately or coherently defined the precise mechanisms by which enslaved people were supposedly "commodified"; second, that the normative position implied by this insistence that persons were treated as things further mystifies or clouds our collective historical vision of enslavement; and third, that future slavery scholarship should abandon a strictly Marxian conception of the commodity — and its close relation to notions of "social death"in favor of Igor Kopytoffs theory of the commodity-as-process. Finally, I offer a reconstituted conceptualization of the slave relation-that is, the social dynamic 
between slaves and those holding power over them-wherein enslaved people are perceived and treated as thoroughly human.

\section{Person and Thing}

One of the most common - and arguably most powerful —rhetorical strategies used by numerous historians of modern racial slavery is to describe the "commodification" of enslaved people as unique to that particular moment in the world-historical development of enslavement: what distinguishes Atlantic slavery in the early modern and modern periods from all other slaveries modern, medieval, or ancient is precisely this "objectification" or "dehumanization" of the slave. This device effectively conveys the supposed uniqueness of transatlantic slavery and implies the urgency of its scholarly analysis. "Unlike any other system of commerce in world history, the primary commodities exchanged in the slave trade were people," writes Lisa Lindsay. "Shocking as this may seem today, most Europeans involved in the slave trade conceived of Africans as physically comparable to other trade goods. . . . Unlike sugar, salt, spices, and textiles-other commodities driving cross-cultural exchange in world history-slaves were human."3 By marking an ethical gap between "most Europeans involved in the slave trade" and contemporary historians and their readers, this passage frames racial slavery and its market logic as jarring and strange-but it tells us little about slavery itself. In such cases, the historical description of slavery and the moral condemnation thereof occur in the same breath. In this sense, references to the "commodification" or "dehumanization" of enslaved humanity are often normative claims masquerading as historical ones.

Consider, for example, the statement that "chattel slavery is the most extreme example we have not only of domination and oppression but of human attempts to dehumanize other people," as embodied in the "unconscionable and unsuccessful goal of bestializing (in the form of pets as well as beasts of burden) a class of human beings." 4 Yet whether slave owners and slave traders were or were not "successful" in their attempts to "bestialize" enslaved persons cannot possibly stand as an historical claim. First, how could we know that the perpetrators of slavery in any of its historical manifestations intended to "bestialize" or "dehumanize" enslaved people? Second, how might we proceed to describe and analyze their intentions? And third, how could we discern whether an enslaved man or woman or child had been successfully "dehumanized," or whether that process had been somehow (by the willpower of the slave?) halted? In such passages, historical empiricism gives way to the supposed moral urgency of the scholar's task. ${ }^{5}$

In some cases, this twist of rhetoric results in such convoluted statements as: "Wherever and whenever masters, whether implicitly or explicitly, recognized the independent will of their slaves, they acknowledged the humanity of their bondpeople. Extracting this admission was, in fact, a form of slave resistance, because slaves thereby opposed the dehumanization inherent in their status." 6 This claim contradicts itself by simultaneously attempting to account for both the "dehumanization" and the humanity of the slave, thereby twisting itself into an unworkable knot whereby the source of enslaved agency is actually located in the person of the slaveholder. Such language is pervasive in the scholarship on slavery. ${ }^{7}$ In fact, it has become commonplace to see slavery itself-as a historical phenomenon-defined as the erasure of the slave's personhood, both in law and in deed. ${ }^{8}$ 
For some, our scholarly objective is to undo or reverse this state of things, so to speak. Walter Johnson, in his well-known article, already gives us reason to approach such rhetorical posturing with extreme caution. One does well to heed his warning that it is not the historian's purpose to grant "agency" or "humanity" to historical actors, least of all the enslaved. Writing history as either a political mode of redress or as an "advertisement of goodwill" does not, after all, do justice to the subject of study. "If we are to draw credibility by doing our work in the name of the enslaved and then seek to discharge our debt to their history by lacknowledging] the moral idiocy and contradictory philosophy of slaveholders," Johnson writes, "then I think that we must admit we are practicing therapy rather than politics: we are using our work to make ourselves feel better and more righteous rather than to make the world better or more righteous." 9

I echo Johnson's claim, with the added caveat that extending the motif of the completely "dehumanized," "commodified," "objectified," or otherwise existentially flattened or socially de-complexified slave does little to articulate the lived experience of enslavement. Rather, it recapitulates an all-encompassing, static, and ahistorical view wherein the "commodified" slave is dominated absolutely by the "commodifying" slaveholder-thereby reproducing a historical paradigm according to which any social action or cultural expression on behalf of the enslaved subject is perceived as always already "resistant" and as needing to be recovered by the enterprising (and morally astute) historian. The historiographical preoccupation with the "commodification" of the slave produces the interpretative circumstances that have led many astray in just the manner Johnson laments.

It should be no surprise that historians of slavery, for decades now, have found this rhetoric analytically enticing. What better way to condemn slavery than to show how it made persons into things? But this particular vocabulary derives from a precise context, and it is not historical inquiry; it derives, of course, from Anglophone abolitionism. ${ }^{10}$ When we talk about "the full enjoyment of the slave as a thing," 11 we are brandishing weapons borrowed from Harriet Beecher Stowe's toolbox —as in the original subtitle to her most famous work: "The Man that Was a Thing." This tendency to revive the (not unproblematic) politics of a bygone era runs rampant in the historiography of slavery. Joseph Miller rightly diagnoses such rhetorical practices as "neo-abolitionist," wherein "the rather stereotyped notion of slavery in both the academic literature and in modern popular culture derives from a nineteenth-century abolitionist negative contrast-in fact a politicized caricature-designed to stir the emotions of an emergently modern world against all limitations of the personal liberties that it seemed to promise."12

The binary opposition of person and thing that undergirds historical work on slavery is a seemingly enthusiastic recycling of imagery perfected by the agents and presses of Anglo-abolitionism that emphasized the "all-but-defining dyad of slavery as an institution." ${ }^{13}$ We should be wary of this habit for two primary reasons. First, the "commodification" of the slave assumes an all-encompassing master-slave dialectic that is arguably not an observable, historical phenomenon but rather "a static abstraction, independent of time or place that we imagine by observing it as such." 14 Second, it keeps us willfully ignorant of the lessons learned from comparative studies of slavery in the Americas. ${ }^{15}$

Decades of historiography, starting with Frank Tannenbaum's classic but flawed study Slave and Citizen: The Negro in the Americas (1946), have emphasized the divergent legal and social practices that shaped colonial slave regimes in 
North America, Latin America, and the Caribbean. Although their methods of inquiry have shifted-from an emphasis on inherited legal codes like the Castilian Siete Partidas to an examination of slaves' claims-making and legal activism-historians have reached the consensus (again and again) that strikingly distinct forms of enslavement, as institution and as process, were manifested in disparate regions of the New World. As there is little room to elaborate on these debates here, suffice it to say that enslaved people throughout Latin America and the Caribbean, specifically in Iberian colonial contexts, were endowed to some extent with formal and informal rights, duties, and obligations rarely observable in North American or Anglo-imperial contexts. ${ }^{16}$

In addition, among the most profound disparities between slavery in North America and in Iberian America was the role of Church and Inquisition institutions, which represented a third relational axis mediating the dynamic between slaveholders and slaves. And last, urban forms of slavery were also common and sometimes as prevalent as the agricultural "plantation complex" in Mexico, Peru, New Granada, Brazil, Cuba, and other regions of Latin America for large stretches of time. To insist on the dyad of "dehumanizing" person and "commodified" thing is to privilege a "neo-abolitionist" image of the antebellum United States as "the single source of the politicized epistemology of studies of slavery as an institution."17

\section{Two Modes of "Commodification"}

With that said, I propose to show exactly how arguments about the "commodification" of the slave break down. The description of the "commodification" of enslaved persons usually takes on two aspects: the representational and the material. ${ }^{18}$ The former refers to the way that perpetrators of slavery imagined or perceived enslaved subjects, often in some abstract way (that is, at a distance). The latter refers to the way that perpetrators of slavery treated enslaved subjects, often in some corporeal way (that is, up close). The act of "commodification" could be articulated differently across time and space.

In terms of the representational mode, the most commonly cited technique of "commodification" was the notational apparatus brought about by the advent of double-entry bookkeeping. "Spanish and Portuguese traders had called young African males piezas or peças - pieces - as if they and their value as potential laborers could be counted like bolts of cloth," writes Vincent Brown. "Women, young children, and the old were designated as fractions of pieces. British slavers numbered their captives outright, according to the sequential order in which they were purchased." ${ }^{19}$ When slaves are thus "called," "counted," "designated," and "numbered" in official commercial documents, Brown rightly notes, we witness how slavers "flatten[ed] the social world [of slaves] by rendering it in the abstract." 20 Stephanie Smallwood has also written in some depth about this practice. "Commodification is fundamentally a representational act," she writes. "Commodification's power resides in language, in discursive forms (ledgers, bills of sale) carefully crafted to define and imagine things in the terms that best facilitate their exchange and circulation." 21

If, as Smallwood claims, "Commodification is fundamentally a representational act," then we should consider the precise dynamics of this representation. Since this notational "commodification" is really a question of historical sources, we should further examine why certain historical circumstances gave rise to particular 
modes of representation and documentation - the paper trails that enable historians to write about slavery in the first place, even while acknowledging the analytical (and ethical) problems they may pose. First, the "discursive forms" responsible for such representational "commodification"-double-entry account books, bills of sale, etc.- -are in many cases tied to specific imperial contexts. That is, specific regimes of power produced particular kinds of documentation; the representational genres described by Smallwood and Brown were indeed characteristic of slavery in the Anglo-American Atlantic, but not necessarily in Iberian, Francophone, or even African contexts. If we tie "commodifying" practices to the production of particular modes of documentation, then it is increasingly difficult to argue that slavery itself was definitionally the "commodification" of enslaved humanity. Could it be argued that slave-trading under the auspices of the British Empire was more "commodifying" than in other imperial contexts due to its particular mode of record-keeping? How might we describe the representation of enslaved people by other "discursive forms"- say, perhaps, the diaries of Moravian missionaries in the West Indies? ${ }^{22}$

It is worthwhile, moreover, to assess whether such notational representation was unique to slavery and slaves (and therefore essential to its perpetration). Ian Baucom's discussion of the 1781 Zong massacre and the concurrent burgeoning of global finance capitalism should complicate the image of this seemingly violent representational act. ${ }^{23}$ Baucom deftly shows how the financial revolution of the eighteenth century and its culture of speculation were accompanied by, or rather enabled by, a significant "epistemological revolution." "The credit financing that both accompanied the slave trade and, in partnership with the trade, fueled an Atlantic cycle of accumulation entailed more than a revolution in accounting procedures. It demanded an epistemological revolution [that] transformed the epistemological by fantasizing it, altered the knowable by indexing it to the imaginable," Baucom writes. "If the epistemological was transformed so too were the ontological and phenomenological convictions of society revolutionized as both the thingly and the perceptible quality of things found themselves fictionalized but credited as no less real for their increasingly theoretical existence." 24

What Baucom suggests here is that enslaved people were not unique in their "fictionalized" representation. This transformation from the "knowable" to the "imaginable" describes an Atlantic world of credit and insurance that enables complex transactions to take place in the absence of material goods-an Atlantic world that enables the captain of the Zong to throw 133 slaves one-by-one overboard off the coast of Jamaica in order to redeem the insurance claim to his cargo, his captives. The imaginative properties of this Atlantic world were bolstered by certain "historicist" practices that emphasized the "type" and the "typical" as sources of knowledge. The paradigm of this practice was double-entry bookkeeping, the very technique that signaled a "revolution in accounting." And while Brown and Smallwood quite fairly note the violence of representing or equating humanity with numeracy, it is critical yet to place this supposed violence within the "epistemological revolution" that Baucom describes.

His account includes excerpts from the meeting minutes of the Lords Commissioners of the Admiralty from the month of July 1783 that indicate how the Commissioners "spent the majority of their time calibrating a fine and exact scale of recompense for those far-flung workmen of the empire whose bodies had 
been wounded in the service of the crown." 25 So, for example, there are several entries like this one:

To Thomas Sutton, clerk in the storekeeper's office in Jamaica, who lost his sight by a "violent inflammation" in January 1782: 40 pounds.

To Captain John Thomas, who had received "many dangerous wounds," including "one through his lungs, one through his bladder, and now has seven balls lodged in his body which cannot be extracted": 150 pounds a year and half pay. ${ }^{26}$

This section of the minute book is analogous to the "commodifying" numeracy of a slave trader's account books. The two share "the imperturbable search for an alternate, alinguistic grammar of commensurability, the casual pursuit of a financializing, decorporealizing logic of equivalence." 27 As Baucom argues, this minute book is haunted by "something the Admiralty would decidedly not have wished to associate with its loyal, suffering, subjects: the specter of slavery, the slave auction block, the slave trader's ledger book; the specter, quite precisely, of another wounded, suffering human body incessantly attended by an equal sign and a monetary equivalent." 28 The historical advent of this epistemology of the imaginable and the typical—epitomized by the "theoretical realism" of doubleentry bookkeeping and its "commodifying" logic of representation-indicates how the allegedly "dehumanizing" notational practices of Anglo-American slave merchants might be better understood as part of a larger global shift in the representation of reality according to a speculative culture of finance capital.

This is not to say that Smallwood and Brown are incorrect in asserting that slavers' representations of enslaved people as abstracted "numbers" or "pieces" was objectifying. It was that, but it was also much more than that. And due to the larger historical circumstances that enabled it, it also tells us little about either perpetrators of slavery or their victims. The shortcomings of this approach are further demonstrated by the second, material group of "commodifying" practices - those that were not representational or theoretical at all, but rather embodied in the mundane interactions of slaves and those who held power over them (owners, traders, speculators). My claim is this: Within the material, mundane, and corporeal processes of enslavement - that is, how slavers treated slaves - the supposed practices, theories, or logics of "commodification" inevitably break down because the enslaved subject is always perceived as human through and through.

Smallwood's assertion that commodification is primarily a "representational act" may be profoundly ironic; she elaborates a theory of "commodification" in her groundbreaking Saltwater Slavery: A Middle Passage from Africa to American Diaspora (2007) that largely forgoes this representational mode for one in which "commodification" is primarily achieved through violence enacted upon the body of the slave. These forms of "psychic and social" violence constituted a science of human deprivation that "relied on a scientific empiricism always seeking to find the limits of human capacity for suffering," Smallwood writes. The process of "commodification" involved "probing the limits up to which it is possible to discipline the body without extinguishing the life within." ${ }^{29}$ Smallwood is quite right in describing the transatlantic slave trade as thoroughly dependent upon captives' suffering. What seems less clear in her account is how this science of suffering signifies the alleged phenomenon of "commodification." On the contrary, it strikes 
me that the Middle Passage and its techniques of brutalization were profoundly invested in human frailty. The slave trade did not operate by treating slaves simply as things—objects, commodities, goods—it operated by treating them as persons who could suffer, and it worked to maximize that suffering without hitting the tipping point at which the slave ceases to suffer because it has died.

Smallwood adds that slavers' brutalization of captive Africans "revealed the boundaries of the middle ground between life and death where human commodification was possible." ${ }^{30}$ This "middle ground" was created by forcing captives into "unmitigated poverty," by starving them and holding them in iron chains, by segregating enchained slaves according to sex. In so doing, slavers "reduced people to the sum of their biological parts, thereby scaling life down to an arithmetical equation and finding the lowest common denominator." ${ }^{31}$ Perhaps most crucially, the "commodification" of the slave also entailed the severing of social and communal ties. "Commodification" was an "alienating agenda." 32

Smallwood's analysis of these supposed techniques of "commodification" is thus deeply indebted to Orlando Patterson's concept of social death: "slavery is the permanent, violent domination of natally alienated and generally dishonored persons." ${ }^{33}$ Smallwood finds her "middle ground" in this condition-a legally or socially liminal state between initial enslavement and ultimate manumission and an ontologically liminal state between being and nonbeing: physical life without social life, belonging to no social community yet provisionally incorporated within a larger social order. Smallwood's account is striking in how it maps techniques of "commodification" directly onto Patterson's articulation of "social death." The slave's ontologically liminal space is precisely where "human commodification was possible," where the slave is "reduced" to "currency" by severed social ties, violent domination, and general maltreatment.

Vincent Brown has rightly noted how strict adherence to Patterson's theory of social death can cause serious interpretive problems in the study of slavery. "It is often forgotten that the concept of social death is a distillation from Patterson's breathtaking survey," Brown writes, "a theoretical abstraction that is meant not to describe the lived experiences of the enslaved so much as to reduce them to a least common denominator that could reveal the essence of slavery in an idealtype slave, shorn of meaningful heritage." ${ }^{34}$ The flaw in Smallwood's account is that she allows "the condition of social death to stand for the experience of life in slavery." ${ }^{35}$ Hence, Smallwood's (and others') description of the thoroughly "dehumanized" or "commodified" slave is largely ahistorical; it maps itself directly onto a sociological abstraction, leaving no room for historical contingency or local variation. It presumes the outcome of "commodification" and describes all aspects of enslavement as constituting or producing that outcome.

Indeed, the question that looms over all this analysis is: What aspects of Atlantic slavery, if any, might not have contributed to human "commodification?" If we suppose that captives were bought and sold along the west coast of Africa but that they were reasonably well fed, would these captives still be "commodified?" If slaves were not segregated by sex aboard slave ships, would they still be "commodified?" What if captives were kept in prisons, but not held in chains-would that make a difference? Analyses of the transatlantic slave trade like that above confuse historical contingency with theoretical fact. If anything, Smallwood's emphasis on the biological aspect of "commodification" undermines the very concept itself. Smallwood writes that, "Because human beings were treated as inanimate objects, 
the number of bodies stowed aboard a ship was limited only by the physical dimensions and configuration of those bodies." 36 This assertion that "human beings were treated as inanimate objects" contradicts the earlier statement that slave traders "reduced people to the sum of their biological parts." How can something be both biological and inanimate?

And more, when Smallwood claims that slave merchants were "probing the limits up to which it is possible to discipline the body without extinguishing the life within," she is also revealing slavers' recognition of the continued physical vitality and biological life of the slave. Patterson himself states this outright: "A dead slave, or one incapacitated by brutalization, was a useless slave." ${ }^{37}$ In defining the power relation internal to slavery, Patterson further observes that "Perhaps the most distinctive attribute of the slave's powerlessness was that it always originated . . . as a substitute for death, usually violent death." ${ }^{38}$ And this is because slaves can die. ${ }^{39}$

I contend that even the horrific practices of starvation, torture, and other forms of "psychic and social" violence enacted upon slaves reveal a profound investment in and acknowledgement of the humanity of enslaved people by their enslavers. I use the word "investment" intentionally and ironically to argue that perpetrators of slavery, rather than treating slaves simply as inanimate things, marketable products, or exchangeable commodities_as things — understood them as thoroughly human. "Scientific" efforts to starve African captives rely on the presumption that captives can be starved. To violently subject captives to "unmitigated poverty" and deprive them of their social and familial ties is to make the fundamental concession that enslaved Africans could be violently subjected to poverty, that they could be deprived of social and familial ties. One cannot alienate a cowrie shell or starve a bale of cotton. This social fact is most evident when we venture beyond the representational mode of "commodification" and into the realm of everyday human contact.

The exact terms in which Patterson defines "social death" confirm this much: If the slave is violently dominated, natally alienated, and generally dishonored, then we must recognize that only a human can be so dominated, so alienated, and so dishonored. As Patterson writes, "The counterpart of the master's sense of honor is the slave's experience of its loss. The so-called servile personality is merely the outward expression of this loss of honor." 40 This "experience . . of loss" implies the loss of something that was once there. In sum, Smallwood's stunning account of the Middle Passage-surely the best we have in the literature on slavery - would be enriched by redirecting analytical attention to how this particular historical process hinged upon, rather than depleted, the humanity and vulnerability of its victims.

\section{A Better Model: Commodity-as-Process}

Historians of slavery striving to demonstrate the "commodification" of enslaved people have been led astray by strict adherence not only to Patterson's "social death" but also to Marx's theory of the commodity. In his discussion of the United States' internal slave trade and the sexual abuse of enslaved women, Edward Baptist constructs a theory of commodification that marries Marx's commodity fetishism with Freud's sexual fetishism. This theoretical framework is 
troubling from the start, if only because Marx's formulation of the commodity and commodity fetishism is arguably inapplicable here.

According to Marx, "This Fetishism of commodities has its origin . . . in the peculiar social character of the labour that produces them." ${ }^{41}$ And when Marx mentions "labour," we should assume that he does not mean the reproductive sort. Indeed, Marx's entire conception of the commodity as social use-value is grounded in the dynamic between human labor on one side and human want on the other. The commodity as social use-value is determined by the quantity of human labor embodied within it, representing the labor-time socially necessary for its production. Commodities are "only definite masses of congealed labourtime." ${ }^{42}$ Marx's articulation of commodity fetishism is thus not particularly suited to the perception or treatment of enslaved people.

Baptist's ensuing examination of the "commodification" of enslaved people - regarding the slave sale or auction, and the rape of enslaved womendemonstrates the instability of this rhetoric. In the first case, Baptist describes the "deanimation of enslaved people" as "virtually inanimate articles" 43 and their subsequent "reanimation" as a "lifeless commodity"44 when they are made to pose, flex their muscles, dance, and play instruments or card games in slave pens where traders meticulously examined their bodies. Slaves were made "to demonstrate their salability by outwardly performing their supposed emotional insensibility and physical vitality," ${ }^{45}$ as Walter Johnson writes of Louisiana slave markets. Baptist does not, however, see the apparent contradiction here-that slavers were invested in, dependent upon, the fundamentally human liveliness of their captives. Slaves were not just "reanimated" as "market myths" ${ }^{26}$ but as flesh capable of withstanding immense suffering.

More central to Baptist's amalgam of commodity and sexual fetishism is the frequent rape of enslaved women by slave traders. Several conclusions emerge from his discussion of the slave market and sexual abuse: first, that enslaved women were regarded by their traders as "impassioned" 47 objects; second, that traders used these objects to satisfy their sexual desires, to assert their masculinity, to "erase dependence" and "forget fears" 48 by exerting control over them; and third, that this capacity for sexual objectification was bought and sold in the slave markets of the United States. I maintain, on the contrary, that such historical instances of rape and sexual abuse do not signify the objectification of enslaved women. It seems rather that slave traders took pleasure in the inability of their "fancy maids" to express sexual consent.

This powerlessness on the part of women who were not "people whose opinions must be considered" suggests that these women had opinions that were disregarded, that they had control or power over their lives and bodies that was suppressed. To take such pleasure in the displeasure, the lack of consent, the powerlessness of another is - perhaps counterintuitively — to recognize the humanity of that person. Baptist's brilliant analysis of slave trader correspondences, specifically showing how their coded language of sexual conquest represented enslaved women as "commodities," is less convincing in the material (and nonrepresentational) realm of everyday intimacy. Slavers were always deeply invested in slaves' necessarily human - "frail, sentient, resistant" ${ }^{\text {"49 }}$ - capacity for suffering. ${ }^{50}$

Such analytical inconsistencies are caused not only by the reductive "neoabolitionist" ways we think about slavery but also by the rigid application of inadequate theoretical models. Simply put, Marx's conception of the commodity does 
not work in such studies, perhaps because its static quality does not sufficiently describe a historical experience that is thoroughly processual. As a possible remedy, I suggest that historians of slavery adopt Igor Kopytoff's theory of the commodity-as-process. This model is best suited to our field of inquiry because it reflects the lived experience of enslavement itself. We first must acknowledge that "slavery" refers to a vast and nebulous web of associations and histories. Modern racial slavery, as a world-historical phenomenon, had many moving parts. From the coasts of Africa, to the Atlantic Middle Passage, to the shores of the New World, to the plantations and cities of the Americas, back and forth throughout the internal slave routes - the life of a single slave often comprised an accumulated series of various forms of enslavement. Any one of these stages might vary greatly.

As Walter Johnson writes, the "daily process of the slave trade" involved "Many slaves trades, many versions of what was happening [that] met and were contested in every sale." 51 In order best to understand how "slavery" varied so widely across time and space-how slaves often passed between different modes of enslavement - we must embrace an appropriately flexible and contingent theoretical model. I would suggest further that the very word "slavery" itself is meaningless insofar as it attempts to describe abstractly what was historically a set of changing, disparate, and transitional circumstances and experiences. ${ }^{52}$ That is, enslavement was always profoundly processual in nature-but not just in the sense of bondage and freedom, life and death, being and nonbeing. It was so with respect to itself, with respect to the mundane life of the slave, with respect to the multiple slaveries endured by any single man or woman throughout a lifetime.

Kopytoff acknowledges this precisely: "What we see in the career of a slave is a process of initial withdrawal from a given original social setting, his or her commoditization, followed by increased singularization (or decommoditization) in the new setting, with the possibility of later recommoditization." ${ }^{3}$ This approach enables us to envision the slave not as a static, "commodified" entity but rather as a social figure that moves through various phases of expulsion, marginality, and reincorporation. Kopytoff's formulation is also particularly useful for re-examining the contexts of Smallwood's and Baptist's work, respectively-the slave market (whether on the Gold Coast or in the American South) and the plantation. Commodity-as-process suggests that "The only time when a commodity status of a thing is beyond question is the moment of actual exchange." ${ }^{54}$ Beyond the singular, ephemeral moment of purchase, the enslaved subject is then "decommoditized" in a process Kopytoff calls "singularization," though often (if not always) able to be "recommoditized." As such, the enslaved person in whatever context becomes a "potential commodity," endowed with "an exchange value even if they have been effectively withdrawn from their exchange sphere and deactivated, so to speak, as commodities." 55 In the parlance of our historiography, this is the chattel principle; Kopytoff helps us understand how the plantation laborer, for example, is not definitionally a "commodified" individual but rather a "potential commodity." 56

Commodity-as-process skirts the theoretical and historical pitfalls of the so-called "commodification" of enslaved humanity in four ways. First, it productively revises a strictly Marxian conception of the commodity-fetish. ${ }^{57}$ Second, the observation that the commodity only truly exists in the "moment of actual exchange" enables us to realize that torture, starvation, and rape-the total 
brutalization of the slave-is predicated on the presumed humanity of the victim. Third, it provides a manner of speaking about the "commoditization" of enslaved people without resorting to the normative impulses found in the historiographical opposition between person and thing. And finally, it is thoroughly historical. Miller urges that the global history of enslavement be rethought as a "historical process." 58 Slaving, he writes, was a strategy, not a sociological abstraction or simply an "institution." And he reminds us that the study of enslavement should focus explicitly on humans and humans acting in order to go "beyond the passivity of suffering and domination." 59

Kopytoffs theory of the commodity-as-process offers a suitable vocabulary and theoretical toolkit to meet such an occasion. We might consider, for example, how such framing might have enhanced Smallwood's account of the successive processes of "turning African captives into Atlantic commodities" and "turning Atlantic commodities into American slaves," where instead of the sociological flattening of "social death" we had the dynamism of Kopytoffs description of the multi-phased career of the slave. We might also consider how, from this perspective, the slave auction in Baptist's analysis might render the slave "commoditized" yet not necessarily "lifeless," positioned interstitially such that the commodity status of the slave can be reactivated, deactivated, or potentialized without becoming permanent, definitional, or ontological. Commodity-as-process thus enables us to imagine historical enslavement in new ways that do not make recourse to such static and normative paradigms buttressed by "social death," Marxian commodity fetish, or any other inadequate theoretical position.

\section{Reparative Semantics?}

That we might come to understand enslavement as thoroughly processual has been highlighted by recent scholarship describing the so-called "second slavery." This work maintains that there was a fundamental transformation in the scalar, geographical, and technological aspects of slavery in the nineteenth century that made it both specifically modern and capitalistic. Atlantic slavery was thus reconfigured by the production of new staple commodities (especially cotton) in unprecedented quantities, the sweeping migration of enslaved people as well as slaveholders to regions previously marginal to the Atlantic economy (the Deep South, western Cuba, the interior of Jamaica, and south-central Brazil, among others), the incorporation of biological and technological innovations for harvesting crops, and a newfound reliance on often excessive financial speculation. ${ }^{60}$

The "second slavery" importantly "calls attention to the continual re-formation of slavery" historical embeddedness of racial slavery and the advent of global capitalism. Indeed, the relevant question for historians of slavery is no longer whether slavery was capitalistic - as it may have been for previous generations of scholars who emphasized the premodern, feudalistic, and paternalist aspects of American slavery-but precisely how and why (and when) slavery and capitalism converged so forcefully.

Yet there are still analytical hurdles to overcome in parsing the relation between slavery and capitalism. As John J. Clegg observes, one central problem running throughout this new scholarship is the refusal to define capitalism itself. While several scholars have given names to the phenomena they describeWalter Johnson's "slave-racial capitalism" and Sven Beckert's "war capitalism" 
come immediately to mind-Clegg notes that "by dodging the problem of definition altogether they fail to provide a coherent account of capitalist slavery." ${ }^{2}$ Another unresolved tension in this body of work is the conjunction of historical process and transformation with a critical vocabulary, as described above, that is insufficiently dynamic. Resorting to the concept of enslaved "commodification" in order to highlight the "dehumanizing" features of a highly profitable and financially sophisticated system of production based on unfree labor-in short, that this new kind of slavery "was tightly linked to the intensity and profits of industrial capitalism" 63 - belies the profound rupture at the heart of the "second slavery."

If we can speak of the "commodified" slave in both seventeenth-century Africa and nineteenth-century Mississippi, then it becomes increasingly difficult to argue that "the second slavery defines a distinct period of Atlantic history."64 Moreover, the repeated emphasis on the increasingly strict and, in many cases, tortuous work regimes that compelled enslaved people to produce cotton and sugar in unprecedented quantities at an unprecedented rate in the nineteenth century reveals again slaveholders' profound investment in the laboring, suffering body of the slave. This burgeoning research on mass slavery and its capitalistic aspects would be strengthened by increased attention to how such historical transformations - clearly resonant with a Kopytoffian vocabulary-did not signal the erosion of enslaved peoples' humanity but rather were built upon it.

In addition, this newfound emphasis on slave exploitation and the onset of modern industrial capitalism has resuscitated debates about the language of history. Recent writing has urged the substitution of the phrase "enslaved person" for the word "slave." One article suggests we opt for "enslaved person" because such historical subjects were "humans first, commodities second," thereby "restoring identity, reversing a cascade of institutional denials and obliterations." "Slave," on the other hand, is allegedly a "nonhuman noun." 65 This argument is not new. Deborah Gray White writes in the preface to the revised edition of her seminal study Ar'n't I a Woman?: Female Slaves in the Plantation South (1999) that were she to rewrite her book, she would opt for "enslaved" rather than "slave": "The noun 'slave' suggests a state of mind and being that is absolute and unmediated by an enslaver. 'Enslaved' says more about what happened to black people without unwittingly describing the sum total of who they were." 66 This same rhetoric was later echoed by Daina Ramey Berry, who writes that, "I prefer to use the term 'enslaved' rather than 'slave' because it forces us to consider that bondpeople did not let anyone 'own' them. They were enslaved against their will."67

More recently, such semantic choices have been championed by Baptistwho opts for "enslavers" rather than "slaveowner" or "slavemaster"68 — and Gregory O'Malley, who writes in his Final Passages: The Intercolonial Slave Trade of British America, 1619-1807 (2014) that "the historian [has] little to work with in the quest for more humanizing descriptors. To avoid endless repetition of the commodified term slave, I will often refer to those carried in the slave trade as Africans or simply as people." 69 As above, somehow the word "slave" has become "nonhuman" and "commodified," thereby implying an ontological status of nonbeing thrust upon captive Africans against their will. The repeated idiom of enslaved "commodification" has thus sneakily embedded itself into the language of scholarly inquiry.

The implied conclusion of such lexical uneasiness is that these historical persons were not actually slaves at all: "Enslavers" mistook their captives for "slaves," whose nonextinguishable humanity made the "inhuman" project impossible simply 
by means of their continued existence. But are there really such damned connotations to the word "slave," which surely does not describe an ontological status at all (unless one forces it to), and is there such emancipatory potential in the phrase "enslaved person?"70 These efforts at developing a new glossary for the study of slavery seem not just convoluted and self-gratifying but also profoundly ahistorical. They demonstrate how a mere semantic quip becomes the basis for normative posturing and a shallow attempt at reparative historiography. The way to a more lucid account of the history of enslavement is not by investing analytical or explanatory weight in synonyms, it is by being more precise about what we talk about when we talk about slavery.

The language of historical inquiry is, however, essential to our understanding of the past. "Much of the scholarly work on slavery," Jennifer Morgan writes, "is, indeed, a search for metaphor." ${ }^{, 1}$ Importantly and perhaps unfortunately, metaphors have become central to establishing ethical distance between scholars and their subjects of study. Describing the two central modes of "commodification," the representational and the material, frequently hinges upon a single word. It pervades writing on the subject: slaves were "regarded $a s " 72$ or "seen as" posed as" commodities; ${ }^{75}$ slaves were "treated as" inanimate objects; ${ }_{76}^{76}$ slaves were "designated as" pieces; ${ }^{77}$ slaves were "reanimated as" market myths; ${ }^{78}$ slaves were "masquerading as" human beings; ${ }^{79}$ slaves were "exhibited . . as" desirable possessions; ${ }^{80}$ slaves were "treated simply as "capital" [emphases added]. ${ }^{81}$ This repeated phrasal structure reappears like a motif; its power is to suggest that slaves were not truly commodities, inanimate objects, pieces, myths. Although they were not truly these things, they were perceived, imagined, or treated as such. Scholars thus force an ontological and epistemological rift between themselves and the perpetrators of slavery who supposedly thought and did such things. Another way of putting this is that enslavers wrongly perceived persons as things. Since people are not and cannot truly be commodities, the proposition that any person could become or be transformed ${ }^{82}$ into a commodity should thus be morally repugnant.

From this perspective, to state that slaveholders were capable of this unthinkability is to suggest an ethical detachment from us: they thought possible what we know is impossible and unthinkable. To force this historical and moral fracture is, in a way, to misunderstand and to refuse to understand-perhaps to be unable to understand-historical actors who took part in the world-historical processes of enslavement. Miller warns us of the trappings of such rhetoric, that "unless we make the effort to step far enough outside of our own lives to at least comprehend what all those slavers, and those whom they enslaved, were all about, we end up lamely lamenting the fates of the enslaved, or condemning the slavers as congenitally evil." ${ }^{\prime 3}$

These moral gaps between past and present-upheld by the opposition between person and thing in the study of slavery - are rooted in moral outrage and produce epistemological deficiencies. In this sense, we might consider an alternative notion of the "unthinkable," in the sense that enslavement is difficult to think about within the inherited intellectual framework of Western political economy and political thought. ${ }^{84}$ Many of the questions raised in this essay-Can a person be a thing? - are extremely difficult to parse perhaps mainly because they insist on maintaining an ethical chasm between the historian and the historical subject. Thus, the presumed "commodification" of enslaved humanity obscures more than it reveals. It renders our collective historical vision of enslavement increasingly hazy 
and opaque. Rather than resort to common metaphors that foreground overwhelming normative assumptions and ahistorical abstractions, I propose that we repatriate the human to the core of the slave relation, thereby understanding enslavement not as a binary opposition between person and thing but rather as a set of competing claims made for and against, by and through historical persons in concrete social situations. $^{85}$

\section{Conclusion}

Perhaps surprisingly, Patterson deserves the last word:

Thus there is, we are told, a fundamental problem posed by slavery, the so-called conflict between the treatment of the slave as a thing and as a human being. The formula ends with some ringing piece of liberal rhetoric to the effect that human dignity is irrepressible: 'You may define a person as a thing,' goes the flourish, 'but you cannot treat him as one' (or some such pious statement). The whole formula is, of course, a piece of irrelevance. ${ }^{86}$

I may be guilty of such a "flourish," but presumably for good reason. My aim is not to regurgitate any "ringing piece of liberal rhetoric" but to emphasize how upholding the opposition between person and thing in the study of slavery forges moral and epistemological gaps between the past and present that cannot be overcome. Put otherwise, one wishes that historians of slavery had heeded Patterson's warning: The tendencies described in this essay that have characterized slavery scholarship condemn to the realm of pure abstraction, and thereby recklessly obscure, the material, embodied, and mundane processes of enslavement in the modern era. It is by embracing a contingent and processual framework like that proposed by Kopytoff that we might avoid this deplorable result and approach a history of modern enslavement that is yet more heinous and less unthinkable.

\section{Endnotes}

Many thanks to Walter Johnson for his initial feedback on this paper in Spring 2012 and to the anonymous reviewers at this journal for their incisive criticisms and productive feedback. Address correspondence to Nicholas T Rinehart, Department of English, Harvard University, 12 Quincy Street, Cambridge, MA, 02138. Email: rinehart@g.harvard.edu.

1. "Commodification" and "dehumanization" may not be precisely the same thing. By both terms I mean to suggest the supposed "thingness" of a person whose "humanity" has been in some way compromised or erased. Lesley Sharp suggests that "commodification" signifies "objectification in some form, transforming persons and their bodies from a human category into objects of economic desire" (293), usually by a process of the fragmenting of the body. Sharp does not, however, precisely articulate how "commodification," "objectification," or "dehumanization" differ, how they observably occur, nor why bodies as "objects of economic desire" are exempt from the category of the "human." See Lesley A. Sharp, "The Commodification of the Body and Its Parts" in Annual Review of Anthropology 29 (2000): 287-328.

2. On slaves as a form of money, see Nell Irvin Painter, "Thinking about the Languages of Money and Race: A Response to Michael O'Malley, 'Specie and Species" American Historical Review 99, no. 2 (1994): 396-404; Michael O'Malley, "Response to Nell Irvin Painter," American Historical Review 99, no. 2 (1994): 405-8. Waldstreicher writes that, contrary to historians like Joyce Appleby and Gordon Wood who associate the rise of 
capitalism with democracy and freedom, the "more disturbing and, arguably, ubiquitous results" of capitalism's advent is "human commodification." See David Waldstreicher, "The Vexed Story of Human Commodification Told by Benjamin Franklin and Venture Smith" Journal of the Early Republic 24, no. 2 (2004): 268. For the most recent scholarship on the relationship between capitalism and slavery, see Calvin Schermerhorn, The Business of Slavery and the Rise of American Capitalism, 1815-1860 (New Haven, 2015); Sven Beckert, Empire of Cotton: A Global History (New York, 2014); Greg Grandin, The Empire of Necessity: Slavery, Freedom, and Deception in the New World (New York, 2014); Edward Baptist, The Half Has Never Been Told: Slavery and the Making of American Capitalism (New York, 2014); Walter Johnson, River of Dark Dreams: Slavery and Empire in the Cotton Kingdom (Cambridge, 2013); Seth Rockman, Scraping By: Wage Labor, Slavery, and Survival in Early Baltimore (Baltimore, 2009).

3. Lisa Lindsay, Captives as Commodities: The Transatlantic Slave Trade (Upper Saddle River, 2008), 2.

4. David Brion Davis, Inhuman Bondage: The Rise and Fall of Slavery in the New World (Oxford, 2006), 2-3.

5. Numerous scholars have attempted to show how enslavers' supposed endeavors to "commodify" or "dehumanize" slaves were not successful. Blackburn writes, "The captive Africans who were taken to the Americas were outsiders and did not, to being with, themselves accept the common identity that was thrust upon them. They knew what it was to be a slave, but might consider that they were themselves not rightly enslaved." See Robin Blackburn, The American Crucible: Slavery, Emancipation, and Human Rights (London, 2011), 87. Burnard similarly remarks that, "Slavers tried to deny slaves' full personhood through the commodification of Africans into slaves." See Trevor Burnard, "The Atlantic Slave Trade" in The Routledge History of Slavery, ed. Trevor Burnard and Gad Heuman (London, 2012), 81. Tadman claims that, "Owners might sometimes pretend that slavery was not about 'Negro speculation'- that it was not about turning people into money-but enslaved people knew better." See Michael Tadman, "Internal Slave Trades" in The Oxford Handbook of Slavery in the Americas, ed. Robert L. Paquette and Mark M. Smith (Oxford, 2010), 626. The implication derived from these kinds of statements seems to be that because enslaved people did not consent to being enslaved, they were not really slaves after all. The nonrelevance and ahistoricism of such remarks are discussed in more depth in the later section of this essay on "reparative semantics." It is also worth stating that many Africans enslaved in the Americas came from communities where enslavement was widely practiced. This fact does not mean that slaves consented to their bondage but rather that they may not have perceived their own enslavement as particularly strange or shocking. Recent studies have increasingly attended to the ways in which Africans' knowledge of enslavement practices in African (especially Muslim) communities informed their behaviors as slaves in New World contexts.

6. Philip Morgan, Slave Counterpoint: Black Culture in the Eighteenth-Century Chesapeake and Lowcountry (Chapel Hill, 1998), xxii. This passage is also quoted prominently in Walter Johnson, "On Agency," Journal of Social History 37, no. 1 (2003): 113-24.

7. On the slave as "thing," see Hartman, Lose Your Mother: A Journey along the Atlantic Slave Route (New York, 2007), 87; Hartman, Scenes of Subjection: Terror, Slavery, and Self-making in Nineteenth-Century America (New York, 1997), 55, 86-87, 97. For an account of the "thing" and its relation to property in Western philosophy and jurisprudence, see Stephen Best, The Fugitive's Properties: Law and the Poetics of Possession (Chicago, 2004), 31n8, 112, 125. The overwhelmingly common tendency to write about the slave as "thing" is due to the fact that enslaved people were purchased as "property." See, for example, Jeff Forret and Christine E. Sears, eds., New Directions in Slavery Studies: Commodification, Community, Comparison (Baton Rouge, 2015). Patterson, however, 
actually rejects this notion outright, arguing that the ownership of a person is not a constituent element of the slave relation. He writes: "Proprietary claims and powers are made with respect to many persons who are clearly not slaves. Indeed any person, beggar or king, can be the object of a property relation. Slaves are no different in this respect." He goes further to state: "The whole weight of Anglo-American jurisprudence, as well as the sociology and economics of property, comes down heavily against the validity of such a concept. Why is this? Because, first, in sociological and economic terms (as in the view of common law) there can be no relation between a person and a thing. Second, relations between persons with respect to some object are always relative, never absolute." See Orlando Patterson, Slavery and Social Death: A Comparative Study (Cambridge, 1982), 20-21. For perspectives on the African context, see Miers and Kopytoff, "African 'Slavery' as an Institution of Marginality" in Slavery in Africa: Historical and Anthropological Perspectives, ed. Suzanne Miers and Igor Kopytoff (Madison, 1977), 21-22; and Jane I. Guyer, "Introduction: Wealth in People, Wealth in Things," Journal of African History 36, no. 1 (1995): 83-90.

8. Despite their significant methodological divergences, both Davis and Miller mention the supposed paradox that slavery "was an institution dedicated to their [slaves'] ultimate dehumanization." See David Brion Davis, "Slavery, Sex, and Dehumanization," Sex, Power, and Slavery, ed. Gwyn Campbell and Elizabeth Elbourne (Athens, 2014), 56. Miller calls the historical process of slaving, "the transcending contradiction of dehumanization that it created against the background of modernity." See Joseph Miller, The Problem of Slavery as History: A Global Approach (New Haven, 2011), 19. Tannenbaum famously argues that in the North American and British imperial contexts, legal codes stripped enslaved people of their "moral personality." He writes: "Legally he was a chattel under the law, and in practice an animal to be bred for the market. The logic of the situation worked itself out in time, but in the process the moral personality of the slave as a human being became completely obscured." See Frank Tannenbaum, Slave and Citizen: The Negro in the Americas (New York, 1946), 82.

\section{Johnson, “On Agency,” 122.}

10. Hence David Brion Davis supports his claim about the "dehumanization" and "bestialization" of the slave by referring to the scene in Frederick Douglass's Narrative of the Life of Frederick Douglass, An American Slave (1845) in which the author fights with the "slave breaker" Edward Covey. This is a classic image in the history of abolitionist literature, demonstrating the centrality of the master-slave dialectic and its chiastic reversal. See Davis, Inhuman Bondage, 2-3. Stanley also writes that, "The intent of abolitionists . . . was hardly to discredit all commodity relations but rather to isolate the market in slaves as a unique and singularly evil form of human commodification," an intent also observable in recent historical studies of slavery. See Amy Dru Stanley, "Wages, Sin, and Slavery: Some Thoughts on Free Will and Commodity Relations," Journal of the Early Republic 24, no. 2 (2004): 285.

\section{Hartman, Scenes of Subjection, 51.}

\section{Miller, The Problem of Slavery as History, 17.}

13. Ibid., 19. Miller's critique of "institutional" approaches to the study resonates well with Bennett's provocation that, "Representations of blackness invariably locate the focus on the exteriority of the slave's experience," which "has come at the expense of any serious examination of slave life and culture." See Herman Bennett, "Writing into a Void: Representing Slavery and Freedom in the Narrative of Colonial Spanish America," Social Text 25, no. 4 (2007): 68.

\section{Miller, The Problem of Slavery as History, 19.}


15. It also keeps us willfully ignorant of the lessons learned from comparative studies of slavery beyond the Americas. Miers and Kopytoff write of African slaveries: "This association of the 'slave' status with a deprived way of life has been reinforced by the picture of plantation slavery, as practiced in the Anglo-American world and as painted during the abolitionist debates of the nineteenth century.... The image of the slave laboring under harsh conditions, exploited, ill-treated and confined to the bottom of the social scale, has come to dominate the Western conception of the essence of slavery. Such, then, was the yardstick against which Westerners measured an institution in other societies to determine whether or not it was 'really' slavery." See Suzanna Miers and Igor Kopytoff, "African 'Slavery' as an Institution of Marginality," 49-50.

16. Such distinctions are further complicated by analyses of local law in the early American republic. See, for example, Laura Edwards, "Enslaved Women and the Law: The Paradoxes of Subordination in the Post-Revolutionary Carolinas," Slavery EF Abolition, 26 no. 2 (2005): 305-23.

17. Miller, The Problem of Slavery as History, x. On slaves' claim-making and comparative legal histories of slavery in the Americas, see Tannenbaum, Slave and Citizen; Alejandro de la Fuente, "Slave Law and Claims-Making in Cuba: The Tannenbaum Debate Revisited," in Law and History Review 22, no. 2 (2004): 339-69; María Elena Diaz, "Beyond Tannenbaum" in Law and History Review 22, no. 2 (2004): 371-76; Christopher Schmidt-Nowara, "Still Continents (And an Island) with Two Histories?" in Law and History Review 22, no. 2 (2004): 377-82. On the role of the Church or Crown as mediating institution between master and slave, see Herman Bennett, Africans in Colonial Mexico: Absolutism, Christianity, and Afro-Creole Consciousness, 1570-1640 (Bloomington, 2003). Zeuske also calls attention to the historiographical preoccupation with the antebellum United States in studies of slavery. He writes: "The hegemony of Anglo-American historiographies threatens a canonization, which is further promoted by a theoretizing history of historiography in central Europe, fixed on the USA, which basically rejects empirical research. The greater part of recent encyclopaedias, textbooks, and atlases of slavery and the slave trade express this hegemony." Zeuske advocates for future studies to emphasize "smaller" slaveries rather than the "great" slaveries that dominate scholarly discourse (antique, Islamic, American plantation slaveries). See Michael Zeuske, "Historiography and Research Problems of Slavery and the Slave Trade in a Global-Historical Perspective," International Review of Social History 57 (2012): 89.

18. There is obviously a third vector here, not discussed at length, which is the law. Debates about whether slave codes and colonial legal regimes construed enslaved people as persons or things have been ongoing for decades. Among the earliest statement on the matter comes from Tannenbaum (see note 7). On the contrary, Patterson writes that, "No legal code I know has ever attempted to treat slaves as anything other than persons in law." See Patterson, Slavery and Social Death, 23. More in line with Tannenbaum, and contra Patterson, is the concept of "civil death" articulated in Colin Dayan, The Law is a White Dog: How Legal Rituals Make and Unmake Persons (Princeton, 2011), 39-70. For the sake of historical perspective, it is worth noting that Frederick Douglass actually came to a conclusion similar to Patterson's in his famed 1852 speech: "Must I undertake to prove that the slave is a man? That point is already conceded. Nobody doubts it. The slaveholders themselves acknowledge it in the enactment of laws for their government. They acknowledge it when they punish disobedience on the part of the slave. There are seventy-two crimes in the State of Virginia, which, if committed by a black man, (no matter how ignorant he be), subject him to the punishment of death . ... What is this but the acknowledgement that the slave is a moral, intellectual and responsible being?" See Frederick Douglass, "What to the Slave is the Fourth of July?: An Address Delivered in Rochester, New York, on 5 July 1852" in The Norton Anthology of African American Literature, ed. Henry Louis Gates, Jr. and Nellie Y. McKay (New York, 1997), 469. 
19. Vincent Brown, The Reaper's Garden: Death and Power in the World of Atlantic Slavery (Cambridge, 2008), 28.

20. Walter Johnson, "The Pedestal and the Veil: Rethinking the Capitalism/Slavery Question," Journal of the Early Republic 24, no. 2 (2004): 5.

21. Stephanie Smallwood, "Commodified Freedom: Interrogating the Limits of Anti-Slavery Ideology in the Early Republic," Journal of the Early Republic 24, no. 2 (2004): 292-93.

22. Thanks to Vincent Brown for suggesting this point in conversation.

23. For more on the Zong case, see James Walvin, The Zong: A Massacre, the Law, and the End of Slavery (New Haven, 2011); Jeremy Krikler, "A Chain of Murder in the Slave Trade: A Wider Context of the Zong Massacre," International Review of Social History 57, no. 3 (2012): 393-415; and Emma Christopher, Slave Ship Sailors and Their Captive Cargoes, 1730-1807 (Cambridge, 2006), 178-80.

24. Ian Baucom, Specters of the Atlantic: Finance Capital, Slavery, and the Philosophy of History (Durham, 2005), 71.

25. Ibid., 6.

26. Ibid.

27. Ibid.

28. Ibid., 7.

29. Stephanie Smallwood, Saltwater Slavery: A Middle Passage from Africa to American Diaspora (Cambridge, 2007), 35-36.

30. Ibid., 34.

31. Ibid., 43.

32. Ibid., 76.

33. Patterson, Slavery and Social Death, 13.

34. Vincent Brown, "Social Death and Political Life in the Study of Slavery," in American Historical Review 114, no. 5 (2004): 1233. Miller also articulates an incisive critique of Patterson's theory of social death: "Patterson's book stakes on slaving on a sweepingly global scale, though not historically.... Slaving is inherently historical. Sociological structures and institutional comparisons cannot capture this fundamental dynamic." See Miller, The Problem of Slavery as History, 20-24.

35. Brown, "Social Death and Political Life," 1236.

36. Smallwood, Saltwater Slavery, 68.

37. Patterson, Slavery and Social Death, 205.

38. Ibid., 5.

39. Burnard echoes Patterson's statement: "Slave captains might not see captives as humans, but as commodities that could be disposed of without ceremony. Nevertheless, they were forced to recognize that captives were peculiar kinds of commodities because they always remained human enough that other humans might 'rise' when a captive was callously murdered." See Burnard, "The Atlantic Slave Trade," 90. Christopher also employs this language in a contradictory manner. She writes: "More significantly, many latter-day Atlantic pirates did not hesitate to use slaves in the manner that their former captains had displayed. In other words, they saw them as disposable commodities." 
Christopher goes on to describe, however, that insurrectionary pirates intended to sell captive Africans for profit. Using the word "disposable" to mean "saleable" profoundly obscures the fact that slaves needed to be kept alive in order to be sold in the first place. See Emma Christopher, Slave Ship Sailors and their Captive Cargoes, 119. On the economic calculation of slave mortality, see Joseph Miller, Way of Death: Merchant Capitalism and the Angolan Slave-Trade, 1730-1830 (Madison, 1988), 657-92.

40. Patterson, Slavery and Social Death, 11-12.

41. Karl Marx, Capital, Volume 1: A Critical Analysis of Capitalist Production, trans. Samuel Moore and Edward Aveling, ed. Friedrich Engels and Dona Torr (New York, 1947), 72.

42. Ibid., 40.

43. Edward Baptist, '“Cuffy,' 'Fancy Maids,' and 'One-Eyed Men': Rape, Commodification, and the Domestic Slave Trade in the United States" in The Chattel Principle: Internal Slave Trades in the Americas, ed. Walter Johnson (New Haven, 2004), 175.

44. Ibid., 177.

45. Walter Johnson, Soul by Soul: Life Inside the Antebellum Slave Market (Cambridge, 1999), 129-30.

46. Baptist, "Rape, Commodification, and the Domestic Slave Trade," 177.

47. Ibid., 169.

48. Ibid., 185.

49. Johnson, Soul by Soul, 29.

50. Burnard approaches this idea when he writes that, "Slaves may have been property, but they were also people, and planters recognized the humanity of their charges as much when they treated slaves harshly as when they exercised other methods of control over them. It was only humans who were responsible for their own actions and who could be punished as slaves were punished." See Trevor Burnard, "The Planter Class" in The Routledge History of Slavery, ed. Trevor Burnard and Gad Heuman (London, 2012), 198.

51. Johnson, Soul by Soul, 16.

52. Miers and Kopytoff write similarly: "For 'slavery' is neither a single idea invented in some particular place from which it spread nor is it a single, clear-cut institution. It is simply an English word, a label, that we feel reasonably comfortable in applying to certain combinations of elements and feel we should not apply to other somewhat different combinations." See Miers and Kopytoff, "African 'Slavery' as an Institution of Marginality," 66. Zeuske rightly claims that "In global history, analysis of slavery should be replaced by the history of slaveries, or of actors in these slaveries, in the tradition of 'small' and kin slaveries, which extend up to the present." See Michael Zeuske, "The Slave Trade in a Global-Historical Perspective," 110.

53. Igor Kopytoff, "The Cultural Biography of Things: Commoditization as Process," in The Social Life of Things: Commodities in Cultural Perspective, ed. Arjun Appadurai, (Cambridge, 1986), 65.

54. Ibid., 83. Christopher also mentions this aspect of Kopytoff's theory but removes his phrase referring to the "relatively short period" during which the slave is commoditized, thereby obscuring Kopytoff's emphasis on the transience or ephemerality of the slave's commodity status. See Christopher, Slave Ship Sailors and Their Captive Cargoes, 167-68.

55. Ibid., 76. 
56. Mintz is perhaps correct, then, to call the slave a "false commodity." Mintz writes: "The important feature of these triangles is that human cargoes figured vitally in their operation.... In both transatlantic triangles the only 'false commodity'-yet absolutely central to the system - was human beings. Slaves were a 'false commodity' because a human being is not an object, even when treated as one. In this instance, millions of human beings were treated as commodities." See Sidney Mintz, Sweetness and Power: The Place of Sugar in Modern History (New York, 1985), 43. Baptist, however, rejects Mintz's analysis: "No doubt Mintz is morally right. Human beings should not be treated as objects, and social conventions that claim that certain people have no humanity or independent personhood are false and contradictory. But as a description of historical forces, his flat denial is incomplete. Commodification is a process that takes place in the eye of the commodifier, not the commodified. In the case of slavery in the Atlantic world, the fictions of commodification were powerful enough to ensure that some people were treated as objects. Slave traders and owners were in practice far from reluctant to treat, think of, and talk about humans as commodities." See Baptist, "Rape, Commodification, and the Domestic Slave Trade," 170.

57. Kopytoff's formulation makes a key revision to Marx's theory of the commodity in the concept of "singularization," or pricelessness—something that can forever cease to have an exchange value either because it is worth too little or because it is worth too much. $\mathrm{He}$ writes: "For Marx, the worth of commodities is determined by the social relations of their production; but the existence of the exchange system makes the production process remote and misperceived, and it 'masks' the commodity's true worth . ... This allows the commodity to be socially endowed with a fetishlike 'power' that is unrelated to its true worth. Our analysis suggests, however, that some of that power is attributed to commodities after they are produced, and this by way of an autonomous cognitive and cultural process of singularization." See Kopytoff, "The Cultural Biography of Things," 83.

\section{Miller, The Problem of Slavery as History, 4.}

59. Ibid., 32. Zeuske also urges the turn away from studying slavery as an "institution." He writes: "The view represented by the author, however (on the basis of field and archival work), that the history of 'slavery' today should be not so much a history of the institution of slavery, but rather and especially a transcultural history of actors, in the first place of slaves of both sexes (because there is least research on these), as well as of individual slaveowners, slave traders, and their ancillaries between the micro and macro history of different spaces (above all seas, oceans, islands and coasts), has not prevailed." See Zeuske, "The Slave Trade in a Global-Historical Perspective," 110.

60. Anthony Kaye, "The Second Slavery: Modernity in the Nineteenth-Century South and the Atlantic World," Journal of Southern History 75, no. 3 (2009): 627-50.

61. Dale Tomich, "The Wealth of Empire: Francisco Arango Y. Parreño, Political Economy, and the Second Slavery in Cuba," Comparative Studies in Society and History 45, no. 1 (2003): 4. For additional works on the "second slavery," see Dale Tomich, "The 'Second Slavery': Bonded Labor and the Transformation of the Nineteenth-Century World Economy" in Rethinking the Nineteenth Century: Movements and Contradictions, ed. Francisco O. Ramirez (Westport, 1988), 103-17; Dale Tomich and Michael Zeuske, "Introduction, the Second Slavery: Mass Slavery, World-Economy, and Comparative Microhistories," in Review (Fernand Braudel Center) 31, no. 2 (2008): 91-100; Michael Zeuske and Javier Laviña, eds., The Second Slavery: Mass Slaveries and Modernity in the Americas and in the Atlantic Basic (Berlin, 2014); and Michael Zakim and Gary J. Kornblith, eds., Capitalism Takes Command: The Social Transformation of NineteenthCentury America (Chicago, 2012). 
62. John J. Clegg, "Capitalism and Slavery," Critical Historical Studies 2, no. 2 (2015): 284. Clegg suggests that historians adopt Robert Brenner's definition of capitalism as "generalized market dependence."

63. Beckert, Empire of Cotton, 92.

64. Tomich and Zeuske, "Introduction, The Second Slavery," 95.

65. Katy Waldman, "Slave or Enslaved Person?" Slate, May 19, 2015, http://www.slate.com/ articles/life/the_history_of_american_slavery/2015/05/historians_debate_whether_to_use_ the_term_slave_or_enslaved_person.html. Similar sentiments on "compromise," "enslaver," and others are discussed in Michael Todd Landis, "These Are Words Scholars Should No Longer Use to Describe Slavery and the Civil War," History News Network, September 4, 2015, http://historynewsnetwork.org/article/160266. An extended debate over the uses of these terms also took place over the H-Slavery online discussion forum. David Blight (rightly, I think) expressed dismay at the conversation: "What, my friends, are we displacing as we continue to discuss this question of terms? In this field we used to debate such questions as whether slaveholders were true capitalists and could also believe in republicanism, whether and how slaves themselves created a rich and abiding expressive culture, and just which layers of the world the slaves made most reshaped American culture generally. We used to debate whether emancipation stemmed from moral or economic impulses. Instead, we seem to love our problem of labels. What happened to the big questions folks?" See David Blight, "Re: use of "enslaved" in H-Slavery, 6 February 2010.

66. Deborah Gray White, Ar'n't I a Woman?: Female Slaves in the Plantation South (New York, 1999), 8.

67. Daina Ramey Berry, "Swing the Sickle for the Harvest Is Ripe": Gender and Slavery in Antebellum Georgia (Urbana, 2007), 167n4.

68. See Edward Baptist, The Half Has Never Been Told: Slavery and the Making of American Capitalism (New York, 2014).

69. Gregory O'Malley, Final Passages the British Inter-colonial Slave Trade, 1619-1807 (Chapel Hill, 2014), 20. He continues his apologia likewise: "Where possible in the pages that follow, I will refer to such African regional 'types' because they are more specific than labels of slave or African, but such labeling falls far short of rendering people in their full and complex humanity. The slave trade's abstraction of people as commodities pervades the surviving documentation and taunts the historian seeking to recover more fully formed individuals." See O'Malley, Final Passages, 21.

70. Even Davis concedes this: "For anyone familiar with the global history of slavery, it is extremely ironic but also understandable that many African Americans today strenuously object to the use of the words 'slave' and 'slaves' when describing their ancestors' people. As we have seen, many Southern slaveholders also wished to avoid those words and succeeded in finding euphemisms for 'slaves' in the U.S. Constitution. Fortunately, there is no need to adopt the clumsy phrase 'enslaved persons' in order to show that inhuman bondage was never successful in dehumanizing a people. In their own rich testimony, American bondsmen described what it meant to be a slave while protecting and preserving a human soul." See Davis, Inhuman Bondage, 330n13.

71. Jennifer Morgan, "Gender and Family Life," in The Routledge History of Slavery, ed. Trevor Burnard and Gad Heuman (London, 2012), 140.

72. Baucom, Specters of the Atlantic, 138.

73. Trevor Burnard, "The Atlantic Slave Trade," 90. 
74. Walsh, "Work and the Slave Economy" in The Routledge History of Slavery, ed. Trevor Burnard and Gad Heuman (London, 2012), 101.

75. Johnson, Soul by Soul, 3.

76. Smallwood, Saltwater Slavery, 68.

77. Brown, Reaper's Garden, 28.

78. Baptist, "Rape, Commodification, and the Domestic Slave Trade," 177.

79. Robin Blackburn, The American Crucible, 11.

80. Christopher, Slave Ship Sailors and Their Captive Cargoes, 168.

81. Dale Tomich, Through the Prism of Slavery: Labor, Capital, and World Economy (Lanham, 2004), 5.

82. Matt D. Childs, "Slave Culture," in The Routledge History of Slavery, ed. Trevor Burnard and Gad Heuman (London, 2012), 174, 177.

83. Miller, The Problem of Slavery as History, 9.

84. Johnson, "The Pedestal and the Veil," 300. Johnson's mention of the "unthinkable" is derived from Dipesh Chakrabarty, Provincializing Europe: Postcolonial Thought and Historical Difference (Princeton, 2000).

85. Thanks to Alejandro de la Fuente for helping to articulate this point.

86. Patterson, Slavery and Social Death, 23. 